\title{
Post-operative analgesic effect of epidural bupivacaine alone and bupivacaine with tramadol for ovariohysterectomy in bitches
}

\author{
Hailemariam Kefyalew ${ }^{1}$, N. Rajendran ${ }^{2}$, Mersha Chanie ${ }^{2}$ and Nateneal Tamerat ${ }^{{ }^{1}}$ \\ ${ }^{1}$ Haramaya University, College of Veterinary Medicine, P. O.Box 138, Dire Dawa, Ethiopia \\ ${ }^{2}$ University of Gondar, Faculty of Veterinary Medicine, P.O. Box 196, Gondar, Ethiopia \\ *Corresponding author: Haramaya University, College of Veterinary Medicine, P. O. Box 138, Dire \\ Dawa, Ethiopia E-mail: natenealtamerat@yahoo.com
}

http://dx.doi.org/10.4314/evj.v20i2.5

\begin{abstract}
Pre-emptive analgesia refers to the application of analgesic before the patient exposal to noxious stimuli. The study was conducted from December, 2013 to May, 2014 on 12 healthy bitches presented to the University of Gondar Teaching Veterinary Clinic for ovariohysterectomy to compare the epidural analgesic efficacy of bupivacaine alone and bupivacaine with tramadol to relieve postoperative pain and asses changes on physiological and heamatological parameters. The bitches were randomly assigned to experimental group I and II. Premedication was done with atropine sulphate and xylazine hydrochloride at $0.04 \mathrm{mg} / \mathrm{kg}$ subcutaneously and $1 \mathrm{mg} / \mathrm{kg}$ intramuscular, respectively. Induction was employed by diazepam at $0.25 \mathrm{mg} / \mathrm{kg}$ intravenous, immediately followed with ketamine hydrochloride at $5 \mathrm{mg} / \mathrm{kg}$ intravenously for effect and maintenance, incremental injections of ketamine hydrochloride was administered. Bupivacaine at $1 \mathrm{mg} /$ $\mathrm{kg}$ was administered epidurally in group I bitches while $1 \mathrm{mg} / \mathrm{kg}$ of bupivacaine combined with $2 \mathrm{mg} / \mathrm{kg}$ tramadol were administered epidurally in group II bitches. Physiological and haematological parameters were assessed at different stages of analgesia, in addition to pain scoring using visual analogue scale (VAS) and categorized numerical rating scale (CNRS). After epidural administration, mean temperature and heart rate between treatment groups showed statistically $(p<0.01)$ high significant reduction while respiratory rate reduction was significant $(\mathrm{p}<0.05)$ in group-II bitches compared to group-I due to the inclusion of opioid analgesic tramadol. Haemoglobin, Packed cell volume, total erythrocyte and leukocyte counts showed a significant $(p<0.05)$ decrease in 1 hour after surgery in both groups. There was a significant $(\mathrm{p}<0.05)$ difference in both visual analogue scale (VAS) and categorized numerical rating Scale (CNRS) score postoperatively in 2 and 6 hours between group I and II bitches. In fact, the visual analogue scale score of group II bitches at 6 hour after surgery was statistically $(p<0.01)$
\end{abstract}


highly reduced compared to group I bitches. In conclusion, postoperative pain assessment revealed better reduction in pain at all intervals in group-II bitches compared to group-I due to the inclusion of opioid analgesic tramadol. However, further studies are needed to compare the efficacy and doses of this combination as epidural analgesic for various surgeries.

Keywords: Bitches, Bupivacaine, Epidural, Ovariohysterectomy, Postoperative pain, Tramadol

\section{Introduction}

International association for the study of pain has defined pain as an unpleasant sensory associated with actual or potential tissue damage (Muir III, 2009). Ongoing pain may cause many detrimental effects to animals, including reduction of food and water consumption, normal respiration interference, increasing rate of postoperative infection and sepsis, reducing mobility which may lead to muscle spasm, and it can delay wound healing (Flecknell, 2000; Grant, 2006). Since all kinds of surgical procedures cause pain to the animal, depending on the severity of tissue injuries, it is very important to alleviate and anticipate the levels of pain associated with surgical procedures in order to choose analgesics and analgesic techniques appropriately. In this regard, incorporation of opioids in anaesthetic protocol with pre-emptive and multimodal analgesia administration has been accepted as the best way in managing pain (Tranquilli et al., 2004).

Preemptive analgesia refers to the application of analgesic before the patient exposal to noxious stimuli whereas multimodal analgesia is the simultaneous administration of two or more analgesic drug or techniques, in order to inhibit nociception through distinct mechanism along pain pathway (Tranquilli et al., 2004). The advantage of preemptive analgesia are the ease in controlling postoperative pain, reducing the dose of anesthetic drugs required, improving patient safety, and providing more effective pain relief (Dobromylskyj et al., 2000). Specifically, pre-emptive epidural analgesia is relevant for postoperative pain relief by suppressing hypersensitivity of neurons and blocking abnormally exaggerated pathways (Valverde, 2008). Epidural analgesia is commonly performed at the lumbosacral intervertebral space and it is effective, safe and relatively easy procedure to perform on dogs to provide analgesia for all structures caudal to the umbilicus (Flaherty and MacGillivray, 2003). Although epidural administration of long acting local anaesthetic like 
bupivacaine has been reported to provide an excellent peri and postoperative analgesia in humans, there are only few reports available on this procedure in veterinary practice (Breivik, 2003).

Tramadol is a centrally acting analgesic which is structurally related to codeine and morphine (Grond and Sablotzki, 2004). The analgesic effect of tramadol is achieved from a complex interaction of at least 3 mechanisms of actions (Lascelles, 2008). First, it acts as a weak opioid agonist. Secondly it is a weak inhibitor of the reuptake of monoamine neurotransmitters. Finally, it is also an alpha 2 adrenoceptor agonist with more binding affinity to the alpha 2A adrenoceptor (Scott and Perry, 2000). Epidural tramadolbupivacaine combination have been used for pain management with success in both efficacy and long duration of analgesia (Majid and Mohammad, 2004; Prakash et al., 2006). However, the use of tramadol by epidural route in dog is quite limited (Natalini and Robinson, 2000; Guedes et al., 2005). In fact, there is no published study on exclusive epidural analgesic efficacy of bupivacaine or its combination with tramadol on ovariohysterectomized bitches in Ethiopia.

At veterinary clinic of Gondar University, ovariohystrectomy in bitches are being done regularly under general anaesthesia. However, the demand for sterilization of bitches is still in raise due to the growing pet animal rearing practice in Gondar. In the postoperative period many bitches are reported to have the compliant of inappeiteance and dullness at post operation. These complaints could be alleviated by including analgesic drugs in the treatment protocol to relief post- operative pain. Hence, this study was designed with the objectives of comparing the post-operative analgesic effect of epidural bupivacaine, exclusively and its combination with tramadol following ovariohysterectomy in bitches. In addition, the study also addresses change in haematological and physiological parameters in both treatment groups.

\section{Materials and Methods}

\section{Study area}

The study was conducted from December 2013 to May 2014 at Teaching Veterinary Clinic of Gondar University located in Gondar town, capital city of North Gondar zone in Amhara regional state, Ethiopia. Gondar is located 727 
$\mathrm{km}$ north western Addis Ababa in Amhara regional state and is 2,220 meter above sea level with $1172 \mathrm{~mm}$ mean annual rainfall and $19.7^{\circ} \mathrm{C}$ average annual temperature. The area is also characterized by two seasons, the wet season from June to September and the dry season from October to May. It is $257 \mathrm{~km} 2$ areas wide (North Gondar Zone Agricultural Bureau, 2011).

\section{Selection of bitches}

Twelve apparently healthy local breed bitches with the same approximate age and body weight registered to the clinics for elective ovariohysterectomy were selected. The age was determined based on the history while the body weight was measured with a digital balance (Table 1 ).

Table 1: Demographic data of the bitches selected for the study

\begin{tabular}{lcc}
\hline $\begin{array}{l}\text { Group } \\
(\mathbf{n}=6)\end{array}$ & $\begin{array}{c}\text { Age in months } \\
\text { (Mean } \pm \mathbf{S E})\end{array}$ & $\begin{array}{c}\text { Body weight in kg } \\
\text { (Mean } \pm \mathbf{S E} \text { ) }\end{array}$ \\
\hline $\mathrm{I}$ & $11.33 \pm 0.33$ & $12.18 \pm 0.08$ \\
$\mathrm{II}$ & $11.17 \pm 0.4$ & $12.27 \pm 0.07$ \\
\hline
\end{tabular}

\section{Experimental Design}

All study animals were assigned to two group's of group I (bupivacaine treated group) or group II (bupivacaine with tramadol treated group) using a complete randomized design (CRD) comprising six bitches in each group with the following anesthetic protocol (Table 2). 
Table 2: Anaesthetic protocol for the experimental design

\begin{tabular}{|c|c|c|c|}
\hline Group & Pre-medication & General anesthesia & Epidural anesthesia \\
\hline Group I & $\begin{array}{l}\text { Atropine sulphate } \\
0.04 \text { milligram per } \\
\text { kilogram body weight } \\
\text { subcutaneous, after } \\
10 \text { minute, Xylaxine } \\
1.0 \text { milligram per } \\
\text { kilogram body weight } \\
\text { intramuscularly. }\end{array}$ & $\begin{array}{l}\text { After } 15 \text { min, } \\
\text { Diazepam } 0.25 \\
\text { milligram per } \\
\text { kilogram body weight } \\
\text { intravenous and } \\
\text { immediately followed } \\
\text { with } 5 \text { milligram per } \\
\text { kilogram of ketamine } \\
\text { given intravenously to } \\
\text { effect. }\end{array}$ & $\begin{array}{l}0.5 \% \text { bupivacaine at dose rate } \\
\text { of } 1 \text { milligram per kilogram } \\
\text { body weight epidurally. }\end{array}$ \\
\hline $\begin{array}{l}\text { Group } \\
\text { II }\end{array}$ & $\begin{array}{l}\text { Atropine sulphate } \\
0.04 \text { milligram per } \\
\text { kilogram body weight } \\
\text { subcutaneous, after } \\
10 \text { minute, Xylaxine } \\
1.0 \text { milligram per } \\
\text { kilogram body weight } \\
\text { intramuscularly. }\end{array}$ & $\begin{array}{l}\text { After } 15 \text { min, } \\
\text { Diazepam } 0.25 \\
\text { milligram per } \\
\text { kilogram body weight } \\
\text { intravenous and } \\
\text { immediately followed } \\
\text { with } 5 \text { milligram per } \\
\text { kilogram of ketamine } \\
\text { given intravenously } \\
\text { to effect. }\end{array}$ & $\begin{array}{l}0.5 \% \text { bupivacaine at dose } \\
\text { rate of } 1 \text { milligram per } \\
\text { kilogram body weight added } \\
\text { with tramadol at dose rate of } \\
2 \text { milligram per kilogram body } \\
\text { weight epidurally. }\end{array}$ \\
\hline
\end{tabular}

\section{Preoperative preparation of bitches}

The bitches in both treatment groups were withheld water and food for 6 and 12 hours before surgery, respectively and they were assessed for fitness to surgery with body temperature, respiratory rate, heart rate, haemoglobin, PCV, total erythrocyte (TEC) and leucocyte count (TLC). In all bitches, right flank and lumbosacral space hair was shaved and the skin was washed aseptically using 7.5 per cent w/v povidone-iodine surgical scrub (Povidone-iodine cleansing solution USP $7.5 \%$ w/v wockhard LTD. Mumbai, India) while the animals were positioned in the left lateral recumbency for ovariohysterectomy. The cephalic vein was catheterized using a 23 Gage (G), 0.75 inch, butterfly catheter (Unolok, Hindustan syringe, Medical devices LTD. Faridabad, India) and secured with adhesive tape around the leg for administration of anesthetic drug and maintenance fluid during anesthesia. 


\section{Anesthetic protocol}

\section{Premedicants, induction and maintenance anesthetics}

Atropine sulphate and xylazine hydrochloride were used as premedication. Injection atropine sulphate (ATN-MB, Martin and Brown-Bioscience, Baddi, India) $0.5 \mathrm{mg} / \mathrm{mL}$ was used in the present study. Xylazine hydrochloride was used as a safe anaesthetic adjunct of ketamine hydrochloride to induce short periods of surgical anaesthesia which improve visceral analgesia and muscle relaxation. Injection Xylaxin ${ }^{\circledR}$, (Indian Immunologicals ltd., Hyderabad, India) $20 \mathrm{mg} / \mathrm{mL}$ was used in the present study.

Since diazepam had calming, muscle relaxing and anticonvulsant effect, it is used to relieve skeletal muscle spasm in this study. Injection Calmpose ${ }^{\circledR}$, (Ranbaxy laboratories limited, India) $5 \mathrm{mg} / \mathrm{mL}$ was used in the present study as an induction agent. Finally, Injection Ketamine hydrochloride (USP, Rotexmedica, Trittau, Germany) $50 \mathrm{mg} / \mathrm{mL}$ was used in the present study as an induction agent. In addition, it was used as maintenance of general anaesthesia by incremental intravenous injections.

\section{Epidural analgesia}

Pre operatively once the bitches were at surgical plane of anesthesia, epidural drug administration was performed in all group I and II bitches positioned in sternal recumbency with both hind legs extended forward under the body. The lumbosacral (L7-S1) interspace and iliac prominences was palpated from both the cranial and caudal directions by moving the finger on the dorsal spinous processes of L6 to L7 and S2 to S1 as per Jones (2001). A Quincke type spinal needle $22 \mathrm{G}, 7.8 \mathrm{~cm}$ long was correctly placed on the midline and caudal to the L7 spinous process and inserted until a distinct popping sensation was felt as the needle penetrates the interarcuate ligament as per Thurmon et al. (1996). Hanging drop technique was used to confirm the correct position of the spinal needle within the epidural space. A drop of normal saline was instilled into the hub for checking needle patency placement and the drug was administered after confirming the needle in epidural space according to the procedure described by Torske et al. (2000).

Bupivacaine injection ANAWIN*, (Neon laboratories limited, Mumbai, India) was used in treatment group I bitches while bupivacaine combined 
with tramadol Injection Zetodol $®$, (zeta life sciences (p) ltd., India) was used in treatment group II bitches in the present study. Bitches were monitored, for any side effects related to epidural analgesics after surgery.

\section{Physiological parameters}

In both groups rectal temperatures, respiratory rate and heart rate were recorded before premedication, after epidural administration, at 1,2 and 6 hours postoperatively. Rectal temperature in degree Celsius $\left({ }^{\circ} \mathrm{C}\right)$ was recorded using a clinical thermometer, the heart rate in beats per minute was recorded using a stethoscope and respiratory rate in breaths per minute was recorded by counting the thoraco-abdominal movements.

\section{Haematological parameters}

In both groups $5 \mathrm{ml}$ of blood samples from cephalic vein using $10 \mathrm{ml}$. Ethylenediamine tetra acetic acid (EDTA) test tube were collected for estimation of Haemoglobin (Hb),packed cell volume (PCV), Total erythrocyte count (TEC) and Total erythrocyte count (TLC) before premedication, after epidural administration, after surgery at 1,2 and 6 hours. Hb was recorded in gram per decilitre (gm/dl) using acid hematin method, PCV was recorded in percentage by microhaematocrit method, TEC was calculated in millions per cubic millimetre (106/cu $\mathrm{mm})$ by dilution and chamber technique using Hayems fluid (Red blood cell (R.B.C) diluting fluid) and TLC was calculated in thousands per cubic millimetres $\left(10^{3} / \mathrm{cu} \mathrm{mm}\right)$ by standard dilution technique using White blood cell (W.B.C) diluting fluid as per the methods described by Benzamin (1985).

\section{Pain assessment parameters}

Pain scoring was determined in both groups before premedication, postoperatively at 1, 2 and 6 hours using VAS and CNRS. The efficacy of drugs under trial in terms of their analgesic properties were compared on the basis of VAS scoring system with 0 to 10 score as described by Mathews et al. (2001) (Table 3) and in CNRS scoring system as described by Conzemius et al. (1997) (Table 4). 
Table 3: Observations of behaviour and physiological parameters to assess pain in bitches at different stage of analgesia, VAS scoring system

\begin{tabular}{lcl}
\hline Observation & Score & Criteria \\
\hline No pain & 0 & $\begin{array}{l}\text { Patient running, playing, eating, jumping and bouncy, } \\
\text { sitting, walking sleeping comfortably. Normal, affectionate } \\
\text { and responsive to care giver. }\end{array}$ \\
Probably no pain & 1 & $\begin{array}{l}\text { Patient appears to be normal. Heart rate normal or } \\
\text { slightly increased }\end{array}$ \\
Mild discomfort & $2 \quad \begin{array}{l}\text { Patient eats and sleeps normally. May resist palpation } \\
\text { of the surgical wound but otherwise shows no other signs } \\
\text { of discomfort. Not depressed. There might be a slight } \\
\text { increase in respiratory rate, heart rate or not increased. }\end{array}$
\end{tabular}

Mild pain

Mild to moderate pain

Moderate pain

Increased moderate pain

Moderate to severe pain

Severe pain

Severe to excruciating

Excruciating pain
3 Patient limps or guards incision and looks a little depressed and not comfortable. Appears to be interested in food and may still eat a little but somewhat picky.

4 The patient resists touching of the operative site. The patient might sit or lie in an abnormal position and was not curled up or relaxed. May or may not be interested in food, might whimper occasionally, be slow to rise, and hang the tail down.

5 Condition progressing from above or patient reluctant to move depressed, inappetant and may bite or attempt to bite when the caretaker approaches the painful area. The patient may vocalize when caretaker attempts to move the patient or when it was approached.

6 Respiratory rate might be increased with abdominal lift and pupils might be dilated.

7 The patient was very depressed and not concerned with its surroundings. The patient may urinate and defecate without attempting to move and cries out with slight movement or might spontaneously cry and continually whimper.

8 Vocalizing might be more of a feature of being so consumed with pain, the patient may not notice caretaker presence. The patient might thrash around the cage intermittently. The patient might scream when being approached. Tachycardia and tachypnoea was present.

9 The patient might scream when being approached and patient was hyper esthetic. The patient might tremble involuntarily when any part of the body in close proximity to wound, injury, was touched.

10 Patient expresses piercing screams or almost comatose. The patient might be hyper esthetic or hyperalgesic. The whole body may tremble, and pain might be elicited wherever the patient was touched. 
Table 4: Observations of vocalization, movement and agitation used to score pain in bitches at different stage of analgesia, CNRS scoring system

\begin{tabular}{lcl}
\hline Observation & Score & Criteria \\
\hline Vocalization & 0 & No vocalizing \\
& 1 & $\begin{array}{l}\text { Vocalizing responds to calm voice and } \\
\text { stroking } \\
\text { Vocalizing does not respond to calm } \\
\text { voice and stroking. }\end{array}$ \\
& 2 & None \\
Movement & 0 & Frequent position change \\
& 1 & Thrashing \\
& 2 & \\
Agitation & 0 & Asleep or calm \\
& 1 & Mild agitation \\
Score & 2 & Moderate agitation \\
Source: (Conzemius et al., 1997). & 3 & Severe agitation \\
\hline
\end{tabular}

\section{Statistical analysis}

The physiological and haematological parameter data were analyzed using T-test for those which pass the normality assumption and for those which fail to hold the normality assumption; the non-parametric counterpart (MannWhitney U test) was employed using Minitab 16 between treatment groups. On the other hands, repeated measures ANOVA was conducted for those which pass the normality assumption while for those which fail to hold the normality assumption; the non- parametric counterpart (Friedman Test) was employed using SPSS-20 with in treatment groups. Pain scoring data was collected, analyzed and presented as mean $( \pm \mathrm{SE})$. P- Value $\leq 0.05$ and $\leq 0.01$ were considered as statistically significant and highly significant, respectively.

\section{Results}

\section{Premedication, induction and maintenance of anesthesia}

The subcutaneous administration of atropine sulphate and intramuscularly injection of xylazine hydrochloride in the study provided adequate sedation and facilitated smooth induction of anaesthesia. The intravenous induction 
of anaesthesia using diazepam and ketamine hydrochloride was also found to be adequate and the induction was observed to be smooth in all the bitches. In addition, the incremental dose of ketamine hydrochloride satisfactorily maintained anaesthesia till completion of surgery in all the bitches.

\section{Epidural analgesia}

The exclusive administration of bupivacaine epidurally in group I bitches and its tramadol combination epidural administration in group II bitches had no adverse effects related to epidural analgesic in all bitches.

\section{Physiological parameters}

The rectal temperature, heart rate and respiratory rate recorded during the study in group I and II (table 5). The mean temperature difference between treatment groups was statistically highly significant $(\mathrm{P}<0.01)$ after epidural administration and $1 \mathrm{~h}$ after surgery compared to before premedication and 6 hours after surgery. In both treatment groups the rectal temperature difference after epidural administration and at $1 \mathrm{hr}$ after surgery was statistically $(\mathrm{P}<0.05)$ significant than the periods before premedication and at $6 \mathrm{hr}$ after surgery. The reduction in respiratory rate was statistically significant $(\mathrm{P}<0.05)$ after epidural administration, at 1 and $2 \mathrm{hrs}$ after surgery compared to before premedication and at $6 \mathrm{hr}$ after surgery between treatment group I and II bitches. On the other hands, statistically a highly significant $(\mathrm{P}<0.01)$ decrease in the mean heart rate was observed after epidural administration between treatment groups (Table 5). 
Table 5: Mean ( \pm SE) of rectal temperature, heart rate and respiratory rate of bitches during different stages of analgesia

\begin{tabular}{|c|c|c|c|c|c|c|}
\hline \multirow[t]{2}{*}{ Parameter } & \multirow[t]{2}{*}{ Group } & \multirow{2}{*}{$\begin{array}{c}\text { Before } \\
\text { premedi- } \\
\text { cation }\end{array}$} & \multirow{2}{*}{$\begin{array}{l}\text { After epidural } \\
\text { administration }\end{array}$} & \multicolumn{3}{|c|}{ Postoperative time after } \\
\hline & & & & 1 hour & 2 hours & 6 hours \\
\hline \multirow{2}{*}{$\begin{array}{l}\text { Rectal } \\
\text { Temperature } \\
\left({ }^{\circ} \mathrm{C}\right)\end{array}$} & I & $38.47 \mathrm{cp} \pm 0.20$ & $36.92 \mathrm{aQ} \pm 0.21$ & $36.82 \mathrm{aQ} \pm 0.21$ & $37.58 \mathrm{abp} \pm 0.09$ & $38.23 \mathrm{bcp} \pm 0.18$ \\
\hline & II & $38.65 \mathrm{bcp} \pm 0.16$ & $35.50 \mathrm{ap} \pm 0.36$ & $35.41 \mathrm{ap} \pm 0.28$ & $36.92 \mathrm{abp} \pm 0.30$ & $38.69 \mathrm{cp} \pm 0.16$ \\
\hline \multirow{2}{*}{$\begin{array}{l}\text { Respiratory } \\
\text { rate(breaths per } \\
\text { min) }\end{array}$} & I & $24.75 \mathrm{bcp} \pm 0.31$ & $19.72 \mathrm{aq} \pm 0.46$ & $22.85 \mathrm{bq} \pm 0.59$ & $28.54 \mathrm{dq} \pm 0.34$ & $27.65 \mathrm{bp} \pm 0.21$ \\
\hline & II & $23.67 \mathrm{cp} \pm 0.57$ & $17.70 \mathrm{ap} \pm 0.56$ & $20.75 \mathrm{bp} \pm 0.36$ & $26.73 \mathrm{dp} \pm 0.57$ & $27.00 \mathrm{bp} \pm 0.39$ \\
\hline \multirow{2}{*}{$\begin{array}{l}\text { Heart rate } \\
\text { (beats per min) }\end{array}$} & I & $118.17 \mathrm{cp} \pm 0.53$ & $108.00 \mathrm{aQ} \pm 1.09$ & $117.33 \mathrm{bcq} \pm 0.81$ & $119.50 \mathrm{cp} \pm 0.48$ & $114.83 \mathrm{bp} \pm 1.67$ \\
\hline & II & $118.58 \mathrm{cp} \pm 0.71$ & $102.50 \mathrm{ap} \pm 1.54$ & $114.58 \mathrm{bp} \pm 1.61$ & $119.83 \mathrm{cp} \pm 1.32$ & $113.40 \mathrm{bp} \pm 2.74$ \\
\hline
\end{tabular}

Row-wise group means with different superscript (abcd) differ significantly $(p<0.05)$ and Column- wise group means with different superscript (pq) differ significantly $(p<0.05)$ and those bearing upper case $(P Q)$ differ highly significantly $(\mathrm{p}<0.01)$.

\section{Haematological parameters}

Statistical analysis of haemoglobin, PCV, TEC and TLC determined before premedication, after epidural administration, postoperatively at 1,2 and $6 \mathrm{hrs}$ revealed a significant $(\mathrm{P}<0.05)$ reduction in $\mathrm{Hb}$ level after epidural administration, at 1 and $2 \mathrm{hrs}$ after surgery in both treatment groups compared to before premedication. There was a significant reduction $(\mathrm{p}<0.05)$ in $\mathrm{Hb}$ concentration at 1 and $2 \mathrm{hrs}$ after surgery between the two treatment groups compared to before premedication. Regarding PCV there was significant reduction $(\mathrm{p}<0.05)$ after epidural injection, at 1 and $2 \mathrm{hr}$ after surgery compared to before premedication value in both groups. There was also statistically $(\mathrm{p}<0.05)$ significant difference in PCV at $1 \mathrm{hr}$ after surgery between group I and II bitches.

Total erythrocyte count showed statistically significant reduction $(\mathrm{p}<0.05)$ after epidural administration and postoperatively after $1 \mathrm{hr}$ when compared to before premedication in both group bitches. There was no statistically a 
significant difference $(\mathrm{p}>0.05)$ in TEC at different times between group I and II bitches. Concerning total leucocytes count, there was statistically significant reduction $(\mathrm{p}<0.05)$ in TLC at 1 and 2 hrs after surgery when compared to before premedication in both groups. There was statistically a significant difference $(\mathrm{p}<0.05)$ in TLC after at 1 and $2 \mathrm{hrs}$ after surgery between group I and II bitches (Table 6).

Table 6: Mean ( \pm SE) haemoglobin, packed cell volume, total erythrocyte count and total leucocyte count of bitches during different stages of analgesia

\begin{tabular}{|c|c|c|c|c|c|c|}
\hline \multirow[t]{2}{*}{ Parameter } & \multirow[t]{2}{*}{ Group } & \multirow{2}{*}{$\begin{array}{l}\text { Before } \\
\text { premedication }\end{array}$} & \multirow{2}{*}{$\begin{array}{l}\text { Right } \\
\text { after } \\
\text { epidural }\end{array}$} & \multicolumn{3}{|c|}{ Postoperative time after } \\
\hline & & & & 1hour & 2 hours & 6 hours \\
\hline \multirow{2}{*}{$\begin{array}{l}\text { Hemoglobin(g/ } \\
\text { dL) }\end{array}$} & I & $15.17 \mathrm{cp} \pm 0.33$ & $12.17 \mathrm{ap} \pm 0.74$ & $13.00 \mathrm{abq} \pm 0.68$ & $12.83 \mathrm{aq} \pm 0.33$ & $14.58 \mathrm{bcp} \pm 0.64$ \\
\hline & II & $15.83 \mathrm{cp} \pm 0.42$ & $10.42 \mathrm{ap} \pm 0.42$ & $10.58 \mathrm{ap} \pm 0.37$ & $10.33 \mathrm{ap} \pm 0.42$ & $12.68 \mathrm{bp} \pm 0.48$ \\
\hline \multirow{2}{*}{$\begin{array}{l}\text { Packed cell } \\
\text { volume } \\
\text { (percent) }\end{array}$} & I & $40.48 b \mathrm{~b} \pm 0.26$ & $30.82 \mathrm{ap} \pm 0.82$ & $32.35 \mathrm{aq} \pm 0.83$ & $29.58 \mathrm{ap} \pm 0.42$ & $38.68 \mathrm{bp} \pm 0.54$ \\
\hline & II & $40.50 \mathrm{bp} \pm 0.45$ & $28.08 \mathrm{ap} \pm 0.48$ & $28.08 \mathrm{ap} \pm 0.48$ & $27.58 \mathrm{ap} \pm 0.40$ & $39.26 \mathrm{bp} \pm 0.82$ \\
\hline \multirow{2}{*}{ 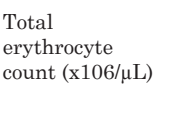 } & I & $6.68 \mathrm{bp} \pm 0.40$ & $5.78 \mathrm{ap} \pm 0.29$ & $5.87 \mathrm{ap} \pm 0.28$ & $7.60 \mathrm{abp} \pm 0.40$ & $6.67 \mathrm{bp} \pm 0.55$ \\
\hline & II & $6.61 \mathrm{bp} \pm 0.33$ & $4.92 \mathrm{ap} \pm 0.30$ & $5.12 \mathrm{ap} \pm 0.07$ & $6.13 \mathrm{ap} \pm 0.39$ & $6.75 \mathrm{bp} \pm 0.51$ \\
\hline \multirow{2}{*}{$\begin{array}{l}\text { Total leukocyte } \\
\text { count }(\mathrm{x} 103 / \mu \mathrm{L})\end{array}$} & I & $13.13 \mathrm{cp} \pm 0.56$ & $13.10 \mathrm{cp} \pm 0.46$ & $10.80 \mathrm{bq} \pm 0.64$ & $7.80 \mathrm{ap} \pm 0.58$ & $14.58 \mathrm{cp} \pm 0.60$ \\
\hline & II & $13.33 \mathrm{cp} \pm 0.40$ & $13.13 \mathrm{bcp} \pm 0.56$ & $7.92 \mathrm{ap} \pm 0.92$ & $11.65 \mathrm{bq} \pm 0.57$ & $13.10 \mathrm{bcp} \pm 0.46$ \\
\hline
\end{tabular}

Row-wise group means with different superscript (abcd) differ significantly $(p<0.05)$ and Column- wise group means with different superscript $(p q)$ differ significantly $(\mathrm{p}<0.05)$.

\section{Pain scores}

The mean $( \pm \mathrm{SE})$ pain scores of VAS and CNRS in two treatment groups of bitches were presented in Table 7 . There was statistically a significant $(\mathrm{P}<0.05)$ difference in the VAS score observed at 2 hours after surgery followed by statistically a highly significant $(\mathrm{P}<0.01)$ difference at 6 hours after 
surgery between treatment groups compared to before premedication. There was statistically a significant $(\mathrm{P}<0.05)$ difference in the VAS score observed postoperatively $1 \mathrm{hr}, 2 \mathrm{hr}$ and $6 \mathrm{hr}$ when compared to before premedication in group I bitches. The pain score at $6 \mathrm{hr}$ after surgery was increased to $3.83 \pm 0.31$ in group I bitches, indicating mild to moderate pain. In Contrast, the pain score in group II at 6 hours after surgery was $1.83 \pm 0.31$ indicating mild discomfort. All the bitches in group I were in lateral recumbency up to $1 \mathrm{hr}$ after surgery while all the bitches in group II were stood within $1 \mathrm{hr}$ after surgery (Table 7).

Regarding, CNRS score there was statistically a significant $(\mathrm{P}<0.05)$ difference observed at 2 hours and 6 hours after surgery between treatment group I and II bitches compared to before premedication. There was also statistically significant $(\mathrm{P}<0.05)$ difference in the CNRS score observed postoperatively 1 hour, 2 hours and 6 hours when compared to before premedication in both groups of bitches (Table 7).

Table 7: Means ( \pm SE) pain scores recorded by visual analog scale and categorized numerical rating scale in bitches during different stages of analgesia.

\begin{tabular}{|c|c|c|c|c|c|}
\hline Parameter & Group & Before & & peratively & \\
\hline & & & 1 hour & 2 hours & 6 hours \\
\hline Visual & I & $0^{\text {ap }}$ & $1.33^{\mathrm{bp}} \pm 0.21$ & $2.17^{\mathrm{cq}} \pm 0.17$ & $3.83^{\mathrm{dQ}_{ \pm 0.31}}$ \\
\hline analog scale & II & $0^{\text {ap }}$ & $1.17^{\mathrm{bp}}{ }_{ \pm 0.17}$ & $1.17^{\mathrm{bp}} \pm 0.17$ & $1.83^{\mathrm{cp}} \pm 0.31$ \\
\hline Categorized & $\mathrm{I}$ & $0^{\text {ap }}$ & $1.50^{\mathrm{bp}}=0.22$ & $2.17^{\mathrm{cq}_{ \pm 0.17}}$ & $3.17^{\mathrm{dq}}{ }_{ \pm 0.31}$ \\
\hline $\begin{array}{l}\text { numerical } \\
\text { rating scale }\end{array}$ & II & $0^{\text {ap }}$ & $1.33^{\mathrm{bp}} \pm 0.21$ & $1.33^{\mathrm{bp}} \pm 0.21$ & $2.00^{\mathrm{cp}} \pm 0.26$ \\
\hline
\end{tabular}

Row-wise group means with different superscript (abcd) differ significantly $(\mathrm{p}<0.05)$ and Column- wise group means with different superscript $(\mathrm{pq})$ differ significantly $(\mathrm{p}<0.05)$ and those bearing upper case $(\mathrm{PQ})$ differ highly significantly $(\mathrm{p}<0.01)$. 


\section{Discussion}

Physiological parameter changes in rectal temperature, heart rate and respiratory rate during the study could be attributed to the epidural analgesia employed. The statistically significant reduction of mean rectal temperature in both treatment groups after epidural administration and $1 \mathrm{hr}$ after surgery in the present study was in agreement with the findings of Hall et al. (2001), Sellon et al. (2001) and Senthilkumar et al. (2009). After epidural administration mean, temperature between treatment groups showed statistically high significant reduction while respiratory rate reduction was significant $(p<0.05)$ after epidural administration (Table 5). This concurs with Flaherty and Musk (2005) who reported reduction in mean rectal temperature due to decreased cardiac output and peripheral vasodilatation.

The mentioned reduction in respiratory rate in group II could be attributed to the inclusion of opioid analgesic, tramadol. Opioids were reported to cause significant dose dependent respiratory depression mediated through receptors leading to a direct depressant effect on brain stem respiratory centres (Tranquilli et al., 2004). Tramadol was reported as a weak inhibitor for the reuptake of noradrenaline and serotonin and possess weak $\mathrm{Mu}$ receptor activity on respiratory centers (Aguiar et al., 2001). Vettorato et al. (2010) also observed respiratory depression after administration of opioids which concurs with the present study. It was probably due to its lipophilicity, rapid absorption and distribution in to brain through epidural vein (Vettorato et al., 2010). However, Holton et al. (1998) reported no correlation exist between respiratory rate and pain in dogs.

This also could be attributed to the minimal cardiovascular depression encountered during anaesthesia. Tramadol was also reported to cause mild cardiovascular depression in bitches (Lee, 2004). On the contrary, Pongphet et al. (2003) and Natalini and Robinson (2006) reported no significant changes in cardiopulmonary function after administration of opoids in bitches. On the other hands, propylene glycol in diazepam is suggested as cardiovascular depressant and may produce hypotension, bradycardia and cardiac arrhythmias Al-Redah (2011).

The haematological changes in haemoglobin, PCV, TEC and TLC recorded in the present study could also be due to epidural analgesia. In fact, the $\mathrm{Hb}$, PCV, TEC and TLC showed a significant $(p<0.05)$ decrease in $1 \mathrm{hr}$ after surgery 
in both groups compared to before premedication (Table 6). The reduction of $\mathrm{Hb}$ and PCV could be attributed to the red blood cell sequestration to the spleen and decreased cardiac output and reduced systemic vascular resistance as reported by Bishop (2005). Blood loss during surgical intervention which would have caused a significant reduction in the $\mathrm{Hb}$ content in the postoperative period (Tranquilli et al., 2004). The observations of the present study concur with the findings of Mishra et al. (1993) who reported significant reduction in the $\mathrm{Hb}$ content in the postoperative period. PCV reduction might be because of the effect of anaesthesia induced adrenergic suppression, resulting in spleenic capsule relaxation and migration of interstitial fluid into the circulating compartment (Tranquilli et al., 2004). Likewise, Sibanda et al. (2006) observed a significant fall in PCV1 hr after epidural analgesia with bupivacaine.

During blood cell counts, there was a significant reduction $(p<0.05)$ in TEC and TLC, in $1 \mathrm{hr}$ postoperatively in both groups of bitches (Tranquilli et al., 2004) (Table 6). Similar finding was also reported by Sibanda et al. (2006). The reduction in RBC could be attributed to blood loss and haemodilution by administration of intravenous fluids (Chandran, 2010). On the other hand, the mentioned TLC reduction in both treatment groups might be due to endogenous corticosteroid release in response to surgery, leucocytic redistribution in peripheral blood resulted from trauma and pain (Bailey and Child, 1987) and reversible deficit at blood lymphocyte produced by acute corticosteroids which was redistributed, recirculated to tissue such as bone marrow (Schultze, 2000).

The mean pain scores of bitches by both VAS and CNRS scales were lower in bitches received epidural bupivacaine with tramadol than with epidural bupivacaine alone (Table 7). This reduction of pain in the group II might be due to block of rostral transmission of nociceptive impulses by binding of spinal opioids receptors as well as prevention of impulses at nerve fibers and endings by local anaesthetics. The present study concurs with Troncy et al. (2002) and Jain et al. (2003) who observed that patient receiving epidural injection of local anaesthetics combined with opioids had a rapid onset of analgesia, more profound and long lasting pain relief than the patients receiving either of these drugs alone. The finding of the present study was also in consistency with those found in human pediatrics undergoing inguinal herniorrhaphy that the addition of tramadol to bupivacaine 
provided longer postoperative analgesia than bupivacaine alone (Taheri et al., 2010). Similarly, Gomez de Segura et al. (2009) indicated epidural tramadolbupivacaine produced longer postoperative motor deficit than bupivacaine alone.

\section{Conclusion}

In conclusion, in both of VAS and CNRS pain evaluations the inclusion of opioid has provided better analgesia for postoperative pain management in ovariohysterectomized bitches without causing any adverse complications. From the above conclusions epidural administration of bupivacaine and tramadol is recommended to control the postoperative pain in ovariohysterectomized bitches, since it deliver a superior and improved duration of analgesia. However, further studies are needed to compare the efficacy and doses of this combination of epidural analgesia for various surgeries.

\section{References}

Al-Redah, S.A.A., 2011. A comparative study between using of midazolam, ketamine and diazepam-ketamine combinations as anaesthetic program in sheep. $A L$ Quadisiya J. Vet. Med. Sci., 10, 66-68.

Benzamin, M. M., 1985. Outline of Veterinary Clinical Pathology. $3{ }^{\text {rd }}$ edn. USA: Iowa State University Press, pp. 55-58

Bishop, Y., 2005. The Veterinary Formulary. $6{ }^{\text {th }}$ edn. London: Pharmaceutical Press, pp. 66.

Breivik, H., 2003. Epidural analgesia for perioperative pain management. Euroanaestheisa, 5, 62-68.

Chandran, J., 2010. Evaluation of acepromazine/xylazine with guaifenesin as preanaesthetic for ketamine induction and isoflurane maintenance anaesthesia in bovine. M. V. Sc. thesis submitted to Tamil Nadu Veterinary and Animal Sciences University, Chennai, Tamil Nadu.

Flecknell, P.A., 2000. Animal pain an introduction. In P.A. Flecknell and A. WatermanPearson, eds. Pain management in animals. Glasgow: Harcourt, pp. 1-7.

Grant, D., 2006. Pain management in small animals. China: Elsevier, 31, 71-85.

Jones, R. S., 2001. Epidural analgesia in the dog and cat. Vet. J., 161 (2), 123-131. 
Lascelles, B.D.X., 2008. Adjunctive drug therapy for canine osteoarthritis pain. Proceeding of the North American Veterinary Conference. Orlando, USA, pp. 1117-1120.

Lee, L., 2004. Ruminant and swine anaesthesia. Vet. Surg. I. VMED., 74(12), 1-15.

Muir III, W.W., 2009. Physiology and pathophysiology of pain. In J.S. Gaynor and W. W. Muir III, ed. Handbook of Veterinary Pain Management. 2 nd ed. China: Mosby, pp.13-41.

Schultze, A.E., 2000. Interpretation of canine leukocyte responses. In Feldman, B. F., Zinkl J. G., Jain, N. C., Hippincott, Wllams and Wilkins, ed. Schalm's Veterinary Haematology. $5^{\text {th }}$ ed. USA: Philadelphia, pp.366-367.

Valverde, A., 2008. Epidural analgesia and anesthesia in dogs and cats. Vet. Clin. Small Anim. 38 (6), 1205-1230.

North Gondar Zone Agricultural Bureau, 2011. Zonal Weather forecasting and work process owner, Gondar, Ethiopia.

Aguiar, A. J., Luna, S.P.L., Oliva, V.N. and Castro, G.B., 2001. Continuous infusion of propofol in dogs premedicated with methotrimeprazine. Vet. Anaesth. Analg., 28, 220-224.

Bailey, P. M., and Child, C. S., 1987. Endocrine response to surgery. In Kaufman. L., ed.

Anaesthesia Review 4. Churchill Livingstone: Edinburgh, pp.100-116.

Conzemius, M.G., Hill, C.M., and Sammarco, J.R., 1997. Correlation between subjective and objective measures used to determine severity of postoperative pain in dogs. J. Am. Vet. Med. Assoc., 240, 1619-1622.

Dobromylskyj, P., Flecknell, P.A., Lascelles, B.D., Pascoe, P.J., Taylor, P., and Waterman-Pearson, A., 2000. Management of postoperative and other acute pain. In Flecknell, P.A. and Waterman-Pearson, A., eds. Pain management in animals. Glasgow, Harcourt, p p.81- 137.

Flaherty, D. and Mac-Gillivary, J., 2003. Analgesia. In E. Welsh, ed. Anaesthesia for veterinary nurses. Padstow: Blackwell, pp.157-178.

Flaherty, D. and Musk, G., 2005. Anaesthetic monitoring equipment for small animals. In Pract., 27, 512-521.

Gomez de Segura, I. A., Menafro, A., Garcia-Fernandez, P., Murillo, S. and Parodi, E. M., 2009. Analgesic and motor-blocking action of epidurally administered levobupivacaine and bupivacaine in the conscious dog. Vet. Anaesth. Analg., 36(5), 485-494.

Ethiop. Vet. J., 2016, 20 (2), 55-73 
Guedes, A. G. P., Natalini, C. C., Robinson, E. P., Alves, S. D. L. and Oliveira, S. T., 2005. Epidural administration of tramadol as an analgesic technique in dogs submitted to stifle surgery. Intern. J. Appl. Res. Vet. Med., 3 (4), 351-359.

Grond, S. and Sablotzki, A., 2004. Clinical pharmacology of tramadol. Clin. Pharmacokinet., 43 (13), 880-923.

Hall, L.W., Clarke, K.W. and Trim, C.M., 2001. Principles of sedation, analgesia and premedication In W.B.Saunders, ed. Veterinary Anaesthesia. $10^{\text {th }}$ ed. USA: Saint Luis, pp.104-107.

Holton, L. L., Scott, E. M. and Nolan, A. M., 1998. Comparison of three methods used for assessment of pain in dogs. J. Am. Vet. Med. Assoc., 212, 61-66.

Jain, P.N., Anup-Arora, S.N. and Myatra G., 2003. Continuous infusion of epidural morphine and Bupivacaine for post operative pain relief. Indian J. Anaesth., 47, 454-455.

Majid, Y., and Mohammad, K., 2004. A comparison of caudally administered single dose bupivacaine and bupivacaine-tramadol combination for postoperative analgesia in children. JK. Science., 6 (1), 19-22.

Mathews, K. A., Pettifer, G., Foster, R. and Mcdonell, W., 2001. Safety and efficacy of postoperative administration of meloxicum compared with that of ketoprofen and butorphenol in dogs undergoing abdominal surgery. Am. J. Vet. Res., 62, 882-888.

Mishra, A.K., and Singh, H., 1993. Effect of bupivacaine $\mathrm{HCl}$ on blood and cerebrospinal fluid composition in unilateral and bilateral segmental epidural and subarachnoid anaesthesia in buffaloes. Indian J. Vet. Surg., 14:1-3.

Natalini, C.C. and Robinson, E.P., 2000. Evaluation of the analgesic effects of epidurally administered morphine, alfentanil, butorphanol, tramadol and U50488H in horse. Am. J. Vet. Res., 61 (12), 1579-1586.

Natalini, C. C. and Robinson, E. P., 2006. Comparative evaluation of the analgesic effects of epideural morphine, alfentenil, butorphanol, tramadol, in horses. Am. J. Vet. Res., 69: 1579-1586.

Pongphet, K., Songkhla , V. N. and Kalpravith, M., 2003. Study of analgesic effect of epidural buprenorphine hydrochloride after fracture repair in dogs. World Small Anim. Vet. Assoc., 1, 1-6.

Prakash, S., Tyagi, R., Gogia, A. R., Singh, R. and Prakash, S., 2006. Efficacy of three doses of tramadol with bupivacaine for caudal analgesia in paediatric inguinal herniotomy. Br. J. Anaesth., 97 (3), 385-388. 
Scott, L.J. and Perry, C.M., 2000. Tramadol: A review of its use in perioperative pain. Drugs. 60 (1), 139-176.

Sellon, D. C., Monroe, V. L. and Roberts, M. C., 2001. Pharmacokinetics and adverse effects of butorphanol administered by single intravenous injection or continuous intravenous injection in horses. Am. J. Vet. Res., 62:183-189.

Senthilkumar, S., Kumaresan, A., Kathirvel, S., Jayakumar, K., Dharmaceelan, S., Rajendran, N. and Nagarajan, L., 2009. Anaesthetic management for transpalpebral exenteration of ocular squamous cell carcinoma in cattle. Indian Vet. J., 86, 1064-1065.

Sibanda, S., Hughes, J. M., Pawson, P. E., Kelly, G. and Bellenger, C. R., 2006. The effects of preoperative extradural bupivacaine and morphine on the stress response in dogs undergoing femoro-tibial joint surgery. Vet. Anaesth. Analg., 33 (4), 246-257.

Taheri, R., Shahnaz, A., Razavi, S.S., Sadeghi, A., Ghabili, K., Ghojazadeh, M. and Rouzrokh, M., 2010. Efficacy of bupivacaine-neostigmine and bupivacainetramadol in caudal block in pediatric inguinal herniorrhaphy. Paediatr. Anaesth., 20 (9), 866-872.

Thurmon, J.C., Tranquilli, W.J. and Benson, G.J., 1996. Local and regional anaesthetic techniques in dogs. In Williams and Wilkins, ed. Lumb and Jones Veterinary Anaesthesia. ${ }^{\text {rd }}$ ed., St.Luis, pp.426-450.

Torske, K. E. and Dyson, D. H., 2000. Epidural analgesia and anaesthesia. Vet. clin. Nor. Am. Small Anim. Pract., 30, 859-874.

Tranquilli, W. J., Lamont, L. A. and Grimm, K. A., 2004. Pain management for the small animal practitioner. 2nd ed. Easy Series. Jackson: Teton NewMedia, pp.1011.

Troncy, E., Junot, S.,Keroack, S., Sammut, V., Pibarot, P., Genevois, J. and Cuvelliez, S., 2002. Results of preemptive epidural administration of morphine with or without bupivacaine in dogs and cats undergoing surgery: 265 Cases (1997-1999). J. Am. Vet. Med. Assoc., 221 (5), 666-672.

Vettorato, E., Zonca, A., Isola, M., Villa, R., Gallo, M., Ravasio, G., Beccaglia, M., Montesissa, C. and Cagnardi, P., 2010. Pharmacokinetics and efficacy of intravenous and extradural tramadol in dogs. Vet. J., 183 (3), 310-315. 